\title{
Effect of Bacillus subtilis C-3102 Spores as a Probiotic Feed Supplement on Growth Performance, Nutrient Digestibility, Diarrhea Score, Intestinal Microbiota, and Excreta Odor Contents in Weanling Piglets
}

\author{
Jing $\mathrm{Hu}^{1,2}$ and In-Ho Kim ${ }^{2, * \mathbb{D}}$ \\ 1 College of Life Science, Linyi University, Shuang Ling Road Middle Section, Linyi 276400, China; \\ ruanjingyi314@163.com \\ 2 Department of Animal Resource \& Science, Dankook University, Cheonan 330-714, Choongnam, Korea \\ * Correspondence: inhokim@dankook.ac.kr; Tel.: +82-41-550-3652; Fax: +82-41-553-1618
}

\section{check for} updates

Citation: Hu, J.; Kim, I.-H. Effect of Bacillus subtilis C-3102 Spores as a Probiotic Feed Supplement on Growth Performance, Nutrient Digestibility, Diarrhea Score, Intestinal Microbiota, and Excreta Odor Contents in Weanling Piglets. Animals 2022, 12, 316. https:// doi.org/10.3390/ani12030316 Academic Editor: José Francisco Pérez

Received: 9 December 2021 Accepted: 26 January 2022 Published: 27 January 2022

Publisher's Note: MDPI stays neutral with regard to jurisdictional claims in published maps and institutional affiliations.

Copyright: (C) 2022 by the authors. Licensee MDPI, Basel, Switzerland. This article is an open access article distributed under the terms and conditions of the Creative Commons Attribution (CC BY) license (https:// creativecommons.org/licenses/by/ $4.0 /)$.
Simple Summary: The weanling period is a vital stage for piglets. Due to lack of a complete digestive system and an immune system, a series of stress problems develop, such as diarrhea. As a kind of microecological additive with high stability and rapid proliferation, Bacillus subtilis is suitable for piglets' diets as an additive. The objective of our study was to determine and confirm the effect of Bacillus subtilis C-3102 spores as a probiotic feed supplement on growth performance, nutrient digestibility, fecal score, intestinal microbiota, and excreta odor contents in weanling piglets. Taken together, our results suggest that dietary supplementation with Bacillus subtilis C-3102 spores could benefit the body weight, average daily gain, and gain-to-feed ratio of weanling piglets and improve the ATTD of dry matter, crude protein, and energy.

\begin{abstract}
It has been well-documented that the dietary supplementation of Bacillus subtilis could improve piglet performance. The present study was conducted to investigate the effect of Bacillus subtilis C-3102 spores as a probiotic feed supplement on growth performance, nutrient digestibility, fecal score, intestinal microbiota, and excreta odor contents in weanling piglets. A total of 150 crossed $(($ Yorkshire $\times$ Landrace $) \times$ Duroc) weanling piglets (28-days-old), with an average initial body weight of $7.53 \pm 1.23 \mathrm{~kg}$, were divided into two treatment groups according to sex and initial body weight (BW) for a 6-week experiment. In each group, fifteen replicate pens consisting of five piglets per pen (three gilts and two barrows) were used in a randomized complete block design. Treatments consisted of (1) CON, a basal diet; (2) BSC, a diet of CON + $300 \mathrm{~g}$ Bacillus subtilis (B. subtilis) C-3102 spores per ton of feed. Supplementation with the B. subtilis C-3102 spores in the diet increased the BW, average daily gain (ADG), and gain-to-feed ratio (G:F) throughout the whole trial $(p<0.05)$. Weanling piglets that were fed B. subtilis C-3102 spores had increased dry matter (DM), crude protein $(\mathrm{CP})$, and energy (E) digestibility compared to the CON group $(p<0.05)$. Lower diarrhea scores were observed in the B. subtilis $C-3102$ spores group on Day $7(p<0.05)$. Taken together, our results suggest that dietary supplementation with $B$. subtilis $C-3102$ spores could benefit the BW, ADG, and G:F of weanling piglets and improve the apparent total tract digestibility (ATTD) of the DM, CP, and E.
\end{abstract}

Keywords: Bacillus subtilis; growth performance; microbiota; nutrient digestibility; weanling piglets

\section{Introduction}

The gastrointestinal peristalsis ability of piglets is weak and gradually shows regular changes with aging until they are 60-90 days old, before approaching the level of adult piglets. Additionally, the nutritional, physiological (for example, the immaturity of the mucosal barrier or weanling from breast milk), and environmental stressors have an adverse impact on the health of piglets and, thus, piglets are prone to diarrhea, stagnant 
growth, and even death in the process of weanling [1,2]. Low gastric acid of piglets lessens the bactericidal properties, allowing pathogenic bacteria to cross the gastric barrier, resulting in poor digestion and absorption of nutrients in piglets. Probiotics can produce various digestive enzymes in animals—such as Bacillus sp., which produces highly active proteases, lipases, and amylases-to reduce certain anti-nutritional factors in feed and degrade some of the more complex carbohydrates in plant feed, thereby improving feed utilization [3,4]. Spores are considered to have stable performance, especially in the process of feed manufacturing and storage [5]. Bacillus subtilis is aerobic or facultatively anaerobic. After entering the gastrointestinal tract, spores colonize the gut, consuming a large amount of free oxygen and inhibiting the growth of harmful aerobic bacteria (Escherichia coli, Streptococcus, Staphylococcus aureus), which results in an enabling environment for other beneficial bacteria (Lactobacillus, Bifidobacterium), that could explain the observed reduction in the incidence of diarrhea in young livestock and poultry [6].

Jeong and Kim (2014) summarized that the main mode of action of B. subtilis C-3102 appears to create an anaerobic environment in the intestines after germination, which is conducive to the growth and proliferation of the natural microbial Lactobacillus, thereby inhibiting intestinal pathogenic bacteria [7]. B. subtilis C-3102 spores have been reported to improve performance and microbiological status in broilers [7-9] and laying hens [10], but there has been limited research on its effect on piglets [11-13], especially weanling piglets. Therefore, this study was conducted to investigate the effect of B. subtilis C-3102 spores as a probiotic feed supplement on growth performance, nutrient digestibility, fecal score, intestinal microbiota, and excreta odor contents in weanling piglets.

\section{Materials and Methods}

All animal-based procedures were done in accordance with the Guidelines for the Care and Use of Experimental Animals of Dankook University (Cheonan, South Korea; approval code: DK-2-1705/2017-02-01).

\subsection{Bacterial Strain}

The final B. subtilis C-3102 product, Calsporin ${ }^{\circledR}$, was provided by a commercial company (Calpis Co. Ltd., Tokyo, Japan) and was composed of spray-dried spore-forming B. subtilis C-3102 endospores (BSC). The final product was determined to contain at least $1.0 \times 10^{9} \mathrm{cfu} / \mathrm{g}$ of $B$. subtilis and was kept in a sterilized container before use.

\subsection{Experimental Design, Animals, and Facilities}

A total of 150 crossed ((Yorkshire $\times$ Landrace) $\times$ Duroc) weanling piglets (28-days-old) with an average initial body weight $(\mathrm{BW})$ of $7.53 \pm 1.23 \mathrm{~kg}$ were divided into two treatment groups according to sex and initial BW in a 6-week experiment. In each group, fifteen replicate pens consisting of five piglets per pen (three gilts and two barrows) were used in a randomized complete block design. The dietary treatment groups were as follows: (1) CON, basal diet; (2) BSC, CON $+300 \mathrm{mg}$ of BSC/ton of feed. The study was divided into Phase 1 (Day 1-7), Phase 2 (Day 8-21), and Phase 3 (Day 22-42), according to the NRC (2012) recommendations for $(($ Yorkshire $\times$ Landrace $) \times$ Duroc $)$ piglets. The diets were formulated to meet or exceed the NRC (2012) nutrient requirements [14]. The piglets were placed in nursery pens $(0.6 \times 2.0 \mathrm{~m} \times 0.5 \mathrm{~m})$ made of stainless steel and a slatted plastic floor in environmentally controlled rooms. Each pen was equipped with a stainless-steel feeder and a nipple drinker that allowed for ad libitum access to feed and water supply during the trial period. A mechanical system of ventilation was applied, and artificial light was automatically provided regularly for $12 \mathrm{~h}$ each day. The indoor temperature was approximately $30^{\circ} \mathrm{C}$, and it decreased by $1{ }^{\circ} \mathrm{C}$ each week during the experiment. The ingredients and chemical composition of the total mixed rations are detailed in Table 1. 
Table 1. Basal diet composition (as-fed basis) [15].

\begin{tabular}{|c|c|c|c|}
\hline Ingredients & Phase 1 (Day 1-7) & Phase 2 (Day 8-21) & Phase 3 (Day 22-42) \\
\hline Extruded corn & 37.39 & 47.90 & 63.36 \\
\hline Soybean meal (dehulled) & 12.00 & 18.00 & 28.40 \\
\hline Fermented soybean meal & 10.00 & 8.00 & - \\
\hline Low-temperature fish meal & 7.60 & 2.70 & - \\
\hline Soy oil & 3.13 & 3.20 & 3.65 \\
\hline Dicalcium phosphate & 1.24 & 1.34 & 1.36 \\
\hline Limestone & 0.60 & 0.74 & - \\
\hline Sugar & 3.00 & 2.00 & 2.00 \\
\hline Whey protein & 11.00 & 8.00 & - \\
\hline Lactose & 12.80 & 6.70 & - \\
\hline L-Lysine HCL & 0.35 & 0.46 & 0.38 \\
\hline DL-Methionine & 0.18 & 0.17 & 0.16 \\
\hline Threonine & 0.21 & 0.29 & 0.19 \\
\hline Choline chloride $50 \%$ & 0.10 & 0.10 & 0.10 \\
\hline Vitamin premix $^{1}$ & 0.20 & 0.20 & 0.20 \\
\hline Mineral premix ${ }^{2}$ & 0.20 & 0.20 & 0.20 \\
\hline Total & 100 & 100 & 100 \\
\hline \multicolumn{4}{|l|}{ Calculated composition } \\
\hline Crude protein, $\%$ & 20.0 & 19.0 & 18.0 \\
\hline Crude fat, \% & 5.40 & 4.80 & 4.40 \\
\hline Calcium, \% & 0.80 & 0.75 & 0.70 \\
\hline Phosphorus, \% & 0.70 & 0.65 & 0.60 \\
\hline Digestible energy, MJ/kg & 16.7 & 16.3 & 15.5 \\
\hline Lysine, $\%$ & 1.60 & 1.50 & 1.30 \\
\hline Methionine, $\%$ & 0.48 & 0.45 & 0.39 \\
\hline Lactose, $\%$ & 20 & 12 & 0 \\
\hline
\end{tabular}

${ }^{1}$ Provided per kilogram of feed: 20,000 IU of vitamin A; $4000 \mathrm{IU}$ of vitamin D3; $80 \mathrm{IU}$ of vitamin E; $16 \mathrm{mg}$ of vitamin K3; $4 \mathrm{mg}$ of thiamine; $20 \mathrm{mg}$ of riboflavin; $6 \mathrm{mg}$ of pyridoxine; $0.08 \mathrm{mg}$ of vitamin B12; $120 \mathrm{mg}$ of niacin; $50 \mathrm{mg}$ of Ca-pantothenate; $2 \mathrm{mg}$ of folic acid; $0.08 \mathrm{mg}$ of biotin. ${ }^{2}$ Provided per kilogram of feed: $80 \mathrm{mg}$ of $\mathrm{FeSO}_{4} \cdot 7 \mathrm{H}_{2} \mathrm{O} ; 140 \mathrm{mg}$ of $\mathrm{CuSO}_{4} \cdot 5 \mathrm{H}_{2} \mathrm{O} ; 179 \mathrm{mg}$ of $\mathrm{ZnO} ; 12.5 \mathrm{mg}$ of $\mathrm{MnO} ; 0.5 \mathrm{mg}$ of $\mathrm{KI} ; 0.25 \mathrm{mg}$ of $\mathrm{CoSO}_{4} \cdot 7 \mathrm{H}_{2} \mathrm{O}$; $0.4 \mathrm{mg}$ of $\mathrm{Na}_{2} \mathrm{SeO}_{3} \cdot 5 \mathrm{H}_{2} \mathrm{O}$.

\subsection{Sampling and Measurements}

At Days $0,7,21$, and 42, the individual piglets' body weights and feed disappearance were recorded to determine the average daily gain (ADG), the average daily feed intake (ADFI), and the gain-to-feed ratio (G:F) in piglets. Chromium oxide $\left(\mathrm{Cr}_{2} \mathrm{O}_{3}, 2 \mathrm{~g} / \mathrm{kg}\right)$ was added to the diets as an indigestible marker during days $36-42$. Fresh fecal grab samples were randomly obtained once by rectal massaging from at least two piglets ( 1 gilt and 1 barrow) in each pen at the end of the experiment to determine the apparent digestibility of dry matter (DM), crude protein (CP), and energy. All samples were stored immediately at $-20^{\circ} \mathrm{C}$ until analysis. The fecal samples were dried at $70{ }^{\circ} \mathrm{C}$ for $72 \mathrm{~h}$ and finely ground to pass through a 1-mm screen [16]. The procedures utilized for the determination of DM (method 930.15) and CP (method 920.39) digestibility were conducted in accordance with the methods described by the AOAC (2000) [17]. Chromium was analyzed via UV absorption spectrophotometry (model UV-1201, Shimadzu, Kyoto, Japan) according to the methods of Williams et al. [18]. The apparent total tract digestibility (ATTD) of DM and CP were also calculated using the methods described by Williams et al. [18]. The gross energy (E) was determined by using a Parr 6100 oxygen bomb calorimeter (Parr Instrument Co., Moline, IL, USA).

At Day 42, the fecal samples of one randomly selected piglet (one gilt and one barrow) each were collected from each pen. They were pooled by pen and placed on ice for transport to the analysis laboratory. One gram of fresh sample from each pen was taken and diluted with $9 \mathrm{~mL}$ of $1 \%$ peptone broth (Becton, Dickinson, and Co.) and homogenized. Viable counts of bacteria in the fecal samples were then determined by plating 10-fold serial dilutions (in $1 \%$ peptone solution) onto MacConkey agar plates (Difco Laboratories, Detroit, 
MI, USA) and lactobacilli medium III agar plates (Medium 638; DSMZ, Braunschweig, Germany) for the isolation of the Escherichia coli (E. coli) and Lactobacillus, respectively. The lactobacilli medium III agar plates were then incubated for $48 \mathrm{~h}$ at $39^{\circ} \mathrm{C}$, and the MacConkey agar plates were incubated for $24 \mathrm{~h}$ at $37^{\circ} \mathrm{C}$ under anaerobic conditions. The $E$. coli and Lactobacillus colonies were counted immediately after removal from the incubator.

At 08.00 and $20.00 \mathrm{~h}$, the diarrhea scores were visually assessed using a subjective score and recorded at Day 0, Day 1-7, Day 15-21, and Day 35-42 by the same person. The diarrhea scores were determined as the average values of five piglets from each pen using a 5-grade score system [19]. The standard of this system is as follows: $1=$ hard, dry pellets in a small, hard mass; 2 = firm, formed stool that remains firm and soft; $3=\mathrm{soft}$, formed, and moist stool that retains its shape; $4=$ loose, unformed stool that assumes the shape of the container; $5=$ watery, liquid stool that can be poured. The scores were recorded for each pen following the observations of individual piglets and signs of stool consistency in the pen.

Fecal samples were collected directly from two piglets (one gilt and one barrow) in each pen at the end of the experiment for the determination of excreta odor contents. A total of $300 \mathrm{~g}$ of fresh feces from each pen were stored in $2.6 \mathrm{~L}$ plastic boxes in replicates. The samples were fermented for $48 \mathrm{~h}$ at a room temperature of $32{ }^{\circ} \mathrm{C}$. After the fermentation period, a Gastec (model GV-100) gas sampling pump was utilized for gas detection (Gastec detector tube No. 3M and 3La for ammonia $\left(\mathrm{NH}_{3}\right)$; No. $4 \mathrm{LL}$ and $4 \mathrm{LK}$ for hydrogen sulfide $\left(\mathrm{H}_{2} \mathrm{~S}\right)$; No. 70 and 70L for total mercaptans, Gastec Corp., Kanagawa, Japan).

\subsection{Statistical Analyses}

The pen was used as the experiment unit and all data were analyzed with SAS version 9.1 (SAS Institute Inc., Cary, NC, USA) using the mixed general linear model procedure. Differences between treatments were detected by Tukey's multiple range test. The results are expressed as the least squares means and standard error. A significant difference level of 0.05 was used to determine statistical significance, and a level of 0.10 was considered a trend.

\section{Results}

\subsection{Growth Performance}

The results of growth performance are summarized in Table 2. Supplementation with B. subtilis C-3102 spores increased the BW by Day 21 and Day $42(p=0.002, p=0.003$, respectively). The inclusion of $B$. subtilis $C-3102$ spores as probiotics improved the ADG in the Day 0-7, Day 8-21, and Day 22-42 periods, as well as during the overall experimental period ( $p=0.044, p=0.029, p=0.014, p=0.004$, respectively). Piglets fed B. subtilis C3102 spores showed significantly higher $(p=0.027)$ ADFI by Day 8-21 and the overall experimental periods $(p=0.041)$. The $\mathrm{G} / \mathrm{F}$ in the overall experimental periods improved significantly $(p=0.011)$ when the piglets were fed B. subtilis C-3102 spores.

Table 2. Effects of B. subtilis C-3102 spores as probiotics on growth performance in weanling piglets ${ }^{1}$.

\begin{tabular}{ccccc}
\hline Items & CON & BSC & SEM $^{2}$ & $p$-Value \\
\hline Body weight, kg & & & & \\
Day 0 & 7.53 & 7.53 & 0.04 & 0.943 \\
Day 7 & 9.01 & 9.21 & 0.06 & 0.068 \\
Day 21 & 14.6 & 15.36 & 0.14 & 0.022 \\
Day 42 & 25.72 & 27.38 & 0.18 & 0.003 \\
ADG, g & & & & \\
Day 0-7 & 212 & 240 & 7 & 0.044 \\
Day 8-21 & 400 & 439 & 8 & 0.029 \\
Day 22-42 & 529 & 573 & 7 & 0.014 \\
\hline
\end{tabular}


Table 2. Cont.

\begin{tabular}{ccccc}
\hline Items & CON & BSC & SEM $^{\mathbf{2}}$ & $p$-Value \\
\hline Overall & 433 & 473 & 5 & 0.004 \\
ADFI, g & & & & \\
Day 0-7 & 270 & 296 & 7 & 0.073 \\
Day 8-21 & 571 & 603 & 7 & 0.027 \\
Day 22-42 & 835 & 842 & 16 & 0.522 \\
Overall & 648 & 671 & 7 & 0.041 \\
G:F & & & & \\
Day 0-7 & 0.788 & 0.813 & 0.014 & 0.254 \\
Day 8-21 & 0.701 & 0.729 & 0.015 & 0.280 \\
Day 22-42 & 0.641 & 0.682 & 0.146 & 0.120 \\
Overall & 0.669 & 0.705 & 0.012 & 0.011
\end{tabular}

${ }^{1}$ Abbreviation: CON, basal diet; BSC, CON + $300 \mathrm{~g}$ B. subtilis C-3102 spores/ton of feed. ${ }^{2}$ Standard error of means.

\subsection{Nutrient Digestibility}

As shown in Table 3, the ATTD of DM in piglets receiving a B. subtilis C-3102 sporesupplemented diet was higher $(p=0.032)$ than that in the CON group. Piglets fed a $B$. subtilis C-3102 spore diet exhibited an increased $(p<0.0001)$ ATTD of CP compared to animals fed the CON diet. In addition, the energy digestibility of piglets fed B. subtilis C-3102 spores was improved ( $p=0.0001)$ compared to the CON group.

Table 3. Effects of B. subtilis C-3102 spores as probiotics on nutrient digestibility in weanling piglets ${ }^{1}$.

\begin{tabular}{ccccc}
\hline Items, $\%$ & CON & BSC & SEM $^{2}$ & $p$-Value \\
\hline Day 42 & & & & \\
Dry matter & 80.77 & 82.02 & 0.33 & 0.032 \\
Crude protein & 77.12 & 80.66 & 0.26 & $<0.0001$ \\
Energy & 76.73 & 81.61 & 0.46 & 0.0001 \\
\hline
\end{tabular}

${ }^{1}$ Abbreviation: CON, basal diet; BSC, CON + $300 \mathrm{~g}$ B. subtilis C-3102 spores/ton of feed. ${ }^{2}$ Standard error of means.

\subsection{Diarrhea Score}

Table 4 shows the results of the fecal scores. Piglets that received diets supplemented with $B$. subtilis C-3102 spores had lower $(p=0.047)$ diarrhea scores compared to the nonsupplemented piglets at Day 1-7. However, no differences were observed at Days 0, 15-21, or 35-42.

Table 4. Effects of B. subtilis C-3102 spores as probiotics on diarrhea scores in weanling piglets ${ }^{1}$.

\begin{tabular}{ccccc}
\hline Items & CON & BSC & SEM $^{2}$ & $p$-Value \\
\hline Diarrhea score $^{3}$ & & & & \\
Day 0 & 3.69 & 3.61 & 0.04 & 0.230 \\
Day 1-7 & 3.69 & 3.54 & 0.04 & 0.047 \\
Day 14-21 & 3.44 & 3.40 & 0.03 & 0.374 \\
Day 35-42 & 3.40 & 3.30 & 0.03 & 0.110 \\
\hline
\end{tabular}

${ }^{1}$ Abbreviation: CON, basal diet; BSC, CON + $300 \mathrm{~g}$ B. subtilis C-3102 spores/ton of feed. ${ }^{2}$ Standard error of means. ${ }^{3}$ Diarrhea scores were determined using the following diarrhea scoring system: 1 -hard, dry pellet; 2-firm, formed stool; 3-soft, moist stool that retains shape; 4-loose, unformed stool that assumes shape of container; 5-watery liquid that can be poured.

\subsection{Intestinal Microbiota}

As illustrated in Table 5, the concentrations of E. coli and Lactobacillus tended to decrease and increase, respectively $(p=0.063, p=0.076)$, when piglets were fed a diet supplemented with B. subtilis C-3102 spores throughout the entire experimental period compared to the $\mathrm{CON}$ group. 
Table 5. Effects of B. subtilis C-3102 spores as probiotics on microbiota in weanling piglets ${ }^{1}$.

\begin{tabular}{ccccc}
\hline Items, $\log ^{10} \mathbf{c f u} / \mathbf{g}$ & CON & BSC & SEM $^{2}$ & $p$-Value \\
\hline Day 42 & & & & \\
E. coli & 5.48 & 5.36 & 0.03 & 0.063 \\
Lactobacillus & 7.51 & 7.64 & 0.04 & 0.076
\end{tabular}

${ }^{1}$ Abbreviation: CON, basal diet; BSC, CON + $300 \mathrm{~g}$ B. subtilis C-3102 spores/ton of feed. ${ }^{2}$ Standard error of means.

\subsection{Excreta Odor Contents}

The results of the excreta odor emissions in piglets are presented in Table 6. The results show that piglets fed with the diet supplementation of B. subtilis C-3102 spores tended to have a decrease $(p=0.053)$ in the concentration of fecal total mercaptan emissions compared to the CON group. However, ammonia $\left(\mathrm{NH}_{3}\right)$ and hydrogen sulfide $\left(\mathrm{H}_{2} \mathrm{~S}\right)$ levels were not affected $(p>0.05)$ by dietary BSC spore supplementation.

Table 6. Effects of B. subtilis C-3102 spores as probiotics on gas emissions in weanling piglets ${ }^{1}$.

\begin{tabular}{ccccc}
\hline Items, ppm & CON & BSC & SEM $^{2}$ & $p$-Value \\
\hline Day 42 & & & & \\
Ammonia & 7.74 & 7.46 & 0.12 & 0.178 \\
Hydrogen sulfide & 5.64 & 5.32 & 0.11 & 0.115 \\
Total mercaptan & 3.32 & 3.14 & 0.05 & 0.053
\end{tabular}

${ }^{1}$ Abbreviation: CON, basal diet; BSC, CON + $300 \mathrm{~g}$ B. subtilis C-3102 spores/ton of feed. ${ }^{2}$ Standard error of means.

\section{Discussion}

As more restrictions are placed on ingredients used in economical animal feed, methods for improving the health performance of piglets by adding additives into feed have received more attention [11]. Weanling piglets often show poor appetites, slow growth, low feed utilization, and diarrhea due to the stress of various factors, such as feed and environment. The beneficial effects of $B$. subtilis supplementation on animal performance have been well-documented in previous studies $[2,11]$. Our results demonstrated that BSC supplementation significantly increased the BW, the ADG, the ADFI, and the G/F compared to the $\mathrm{CON}$ group throughout the whole experiment. The results are in agreement with another study demonstrating highly significant increases in the final BW and ADG compared to the control animals and an improvement in the gain-to-feed ratio in the treated group [20]. Similarly, growth could be promoted when piglets fed diets supplemented with B. subtilis C-3102 (Calsporin $\left.{ }^{\circledR}\right)$ [21]. Significant improvements to performance parameters (final BW, ADG, and G:F) were recorded after Calsporin ${ }^{\circledR}$ (B. subtilis C-3102) consumption [12]. Marubashi et al. (2012) reported that piglets fed diets supplemented with a commercial probiotic product (Calsporin ${ }^{\circledR}$ : B. subtilis C-3102) were significantly heavier (3.4\%) at 43 days. In addition, Michiels et al. (2016) also reported that the piglets fed diets supplemented with B. subtilis C-3102 showed a significant G:F improvement [13]. At present, the mechanism of probiotics that improves animal production performance and promotes growth is not completely understood. Nevertheless, most researchers generally believe that probiotics as feed additives can regulate intestinal flora, promote the digestion and absorption of nutrients, and enhance the immunity of the animal body [22]. In agreement with these results, our study indicated that $B$. subtilis $C-3102$ spores as probiotics improved the BW, ADG, and G:F in weanling piglets. However, some conflicting results were found by other researchers. Regarding BW, Menegat et al. $(2017,2018)$ reported no evidence for differences between piglet diets supplemented with a commercial probiotic product (Calsporin ${ }^{\circledR}$ : B. subtilis C-3102) and those without [5,23]. The different conclusions produced by these studies may be related to the composition of the diet, the age of the piglets, and interactions with environmental factors and dietary feed additives [24]. 
Bacillus spp. can produce a variety of digestive enzymes, such as protease, lipase, and amylase, in the intestinal tracts of animals $[3,25]$. At the same time, many kinds of nutrients, such as amino acid and growth-promoting factors, were produced by Bacillus spp. to promote the metabolisms of animal bodies [26]. Improved digestibility is a key factor in improved performance. In our study, the ATTD of DM, CP, and E were significantly improved by dietary supplementation with $B$. subtilis $\mathrm{C}-3102$ spores. In addition, our results show there were positive effects on the BW, ADG, ADFI, and G/F in the BSC group. In agreement with our study, Kim et al. (2010) reported that the digestibility of DM, CP, and nitrogen was higher in piglets supplemented with bacillus probiotics than in piglets fed a control group diet [27]. In a report by Devi and Kim (2014), the digestibility of DM, N, and $\mathrm{E}$ were found to be increased significantly with a B. bacillus diet when compared to the controls [28]. The research by Patarapreecha et al. (2018) showed that the addition of $B$. bacillus improved the digestion and utilization of proteins and energy in feed components in the starter and growing periods of pigs [29]. Giang et al. (2011) also demonstrated that pigs fed a diet contain B. subtilis had better digestibility of CP [30]. In contrast, several studies reported that the supplementation of bacillus-based probiotics did not affect the $\mathrm{DM}, \mathrm{E}$, or nitrogen digestibility in pigs [31,32]. Due to discrepancies in the ages of the animals, the dose of B. bacillus species, diet composition, feed form, and interactions with other dietary feed additives, certain disagreements have arisen.

One of the effective ways to reduce the incidence of diarrhea is to promote piglets' intestinal development by applying some functional feed additives [33,34]. Maruta et al. (1996) reported that the incidence of diarrhea in piglets was significantly decreased, and a low mortality rate was observed when their sows were fed a diet containing B. subtilis C-3102 for 6 months [8]. Jang et al. (2009) evaluated probiotics as an alternative in weanling piglets and found that feeding them $0.2 \%$ B. subtilis tended to improve the diarrhea scores of weanling pigs [35]. Our results also showed that pigs fed a B. subtilis C-3102 spore diet had lower diarrhea scores compared to non-supplemented piglets. As reported, the impacts of probiotics appeared to be more viable for younger pigs [36]. This may be the reason why the incidence of diarrhea decreased in weanling piglets by Day 7 in our trial.

The imbalance of intestinal microbiota frequently described around weanling is prone to pathogen invasion and is one of the main underlaying reasons for mortality rate postweanling. Bacillus. spp. helps piglets to establish normal microbiota and eliminate or control potential pathogens in addition to promoting the enhancement and improvement of digestive and immune functions in piglets [37,38]. Cui et al. (2013) also demonstrated that adding B. subtilis can manipulate gut microbial communities [39]. Larsen et al. (2014) conducted a principal component analysis (PCA) of pathogen inhibition, and the results showed that B. subtilis strains have the potential to efficiently inhibit pathogenic bacteria in the intestine [40]. Similarly with these studies, our results showed that the concentration of E. coli tended to decrease, and Lactobacillus counts tended to increase when piglets were fed a B. subtilis C-3102 spore-supplemented diet. A previous study on the intestinal microbiota of weaned piglets also showed that $E$. coli concentrations increased while the number of Lactobacillus decreased after weanling [41].

Numerous odorous harmful gases, such as $\mathrm{NH}_{3}, \mathrm{H}_{2} \mathrm{~S}$, and amines emitted from animal manure in intensive livestock and poultry production, have attracted widespread attention from agricultural experts. These harmful gases not only seriously endanger the health of humans and animals but also cause serious ecological problems [42,43]. However, some researchers have discovered that the harmful gases can be decreased by adding probiotics to feed $[32,44,45]$. Chen et al. (2006) reported that fecal $\mathrm{NH}_{3}-\mathrm{N}$ was significantly decreased $(p<0.05)$ when pigs were fed diets supplemented with $0.2 \%$ bacillus-based probiotics compared to pigs fed basal diets [46]. Wang et al. (2009) reported that the dietary application of B. subtilis and B. licheniformis could reduce $\mathrm{NH}_{3}$ emissions [47]. Similarly, Upadhaya et al. (2015) demonstrated that $\mathrm{NH}_{3}$ concentrations appeared to be lower during the growing and finishing phases, and no positive effect was found for other gases such as total mercaptans and $\mathrm{H}_{2} \mathrm{~S}$ [45]. Our results showed that the concentration of total fecal 
mercaptan emissions tended to decrease. In fact, the emission of harmful gases in feces is closely related to the digestive utilization of nutrients in the diet and the intestinal microflora ecosystem [48]. Moreover, Banwart and Brenmer (1975) previously reported that only $0.03 \%$ of the total sulfur present in swine manure was volatilized to sulfur gases over a 30-day incubation period [49]. This may be a reasonable explanation for the lack of significant reductions in the $\mathrm{H}_{2} \mathrm{~S}$ levels. As well, the lesser difference in $\mathrm{NH}_{3}$ may be related with no changes of intestinal microbiota in this study.

\section{Conclusions}

Taken together, our results suggest that dietary supplementation with B. subtilis C-3102 spores could benefit the body weight, the average daily gain, and the gain-to-feed ratio of weanling piglets and could improve the ATTD of DM, CP, and E. Additionally, B. subtilis supplementation had a significant effect on mercaptan emissions, but not on $\mathrm{NH}_{3}$ and $\mathrm{H}_{2} \mathrm{~S}$ levels.

Author Contributions: Conceptualization, I.-H.K.; data curation, J.H.; formal analysis, J.H.; methodology, J.H.; software, J.H.; writing—original draft, J.H.; writing—review and editing, J.H. and I.-H.K. All authors have read and agreed to the published version of the manuscript.

Funding: This research received no external funding.

Institutional Review Board Statement: All animal-based procedures were done in accordance with the Guidelines for the Care and Use of Experimental Animals of Dankook University (Cheonan, South Korea; approval code: DK-2-1705).

Informed Consent Statement: Not applicable.

Data Availability Statement: Not applicable.

Conflicts of Interest: The authors have no known conflicts of interest associated with this publication.

$\begin{array}{ll}\text { Abbreviations } \\ \text { BW } & \begin{array}{l}\text { body weight } \\ \text { B. Subtilis }\end{array} \\ \text { Bacillus subtilis } \\ \text { average daily gain } \\ \text { G/F } & \text { gain-to-feed ratio } \\ \text { DM } & \text { dry matter } \\ \text { CP } & \text { crude protein } \\ \text { E } & \text { energy } \\ \text { Cr } \mathrm{O}_{3} & \text { chromium oxide } \\ \text { ATTD } & \text { apparent total tract digestibility } \\ \text { E. Coli } & \text { Escherichia coli } \\ \mathrm{NH}_{3} & \text { ammonia } \\ \mathrm{H}_{2} \mathrm{~S} & \text { hydrogen sulfide }\end{array}$

\section{References}

1. Laine, T.M.; Lyytikäinen, T.; Yliaho, M.; Anttila, M. Risk factors for post-weaning diarrhoea on piglet producing farms in Finland. Acta Veter.-Scand. 2008, 50, 21. [CrossRef] [PubMed]

2. Hu, Y.; Dun, Y.; Li, S.; Zhao, S.; Peng, N.; Liang, Y. Effects of Bacillus subtilis KN-42 on Growth Performance, Diarrhea and Faecal Bacterial Flora of Weaned Piglets. Asian-Australas. J. Anim. Sci. 2014, 27, 1131-1140. [CrossRef] [PubMed]

3. Priest, F.G. Extracellular enzyme synthesis in the genus Bacillus. Bacteriol. Rev. 1977, 41, 711-753. [CrossRef]

4. Latorre, J.D.; Hernandez-Velasco, X.; Wolfenden, R.E.; Vicente, J.L.; Wolfenden, A.D.; Menconi, A.; Bielke, L.R.; Hargis, B.M.; Tellez, G. Evaluation and Selection of Bacillus Species Based on Enzyme Production, Antimicrobial Activity, and Biofilm Synthesis as Direct-Fed Microbial Candidates for Poultry. Front. Veter.-Sci. 2016, 3, 95. [CrossRef] [PubMed]

5. $\quad$ Menegat, M.B.; Gourley, K.M.; Braun, M.B.; DeRouchey, J.M.; Woodworth, J.C.; Bryte, J.; Tokach, M.D.; Dritz, S.S.; Goodband, R.D. Effects of a Bacillus-Based Probiotic on Sow Performance and on Progeny Growth Performance, Fecal Consistency, and Fecal Microflora. Kans. Agric. Exp. Stn. Res. Rep. 2018, 4, 4. [CrossRef] 
6. Mingmongkolchai, S.; Panbangred, W. Bacillus probiotics: An alternative to antibiotics for livestock production. J. Appl. Microbiol. 2018, 124, 1334-1336. [CrossRef]

7. Jeong, J.S.; Kim, I.H. Effect of Bacillus subtilis c-3102 spores as a probiotic feed supplement on growth performance, noxious gas emission, and intestinal microflora in broilers. Poult. Sci. 2014, 93, 3097-3103. [CrossRef]

8. Maruta, K.; Miyazaki, H.; Masuda, S.; Takahashi, M.; Marubashi, T.; Tadano, Y.; Takahashi, H. Exclusion of Intestinal Pathogens by Continuous Feeding with Bacillus subtilis C-3102 and its Influence on the Intestinal Microflora in Broilers. Nihon Chikusan Gakkaiho 1996, 67, 273-280. [CrossRef]

9. Hooge, D.M.; Ishimaru, H.; Sims, M.D. Influence of Dietary Bacillus subtilis C-3102 Spores on Live Performance of Broiler Chickens in Four Controlled Pen Trials. J. Appl. Poult. Res. 2004, 13, 222-228. [CrossRef]

10. Sohail, S.S.; Bryant, M.M.; Voitle, R.A.; Roland, D.A. Influence of Calsporin on Commercial Leghorns. J. Appl. Poult. Res. 2002, 11, 379-387. [CrossRef]

11. Marubashi, T.; Gracia, M.I.; Vilà, B.; Bontempo, V.; Kritas, S.K.; Piskoríková, M. The efficacy of the probiotic feed additive Calsporin ${ }^{\circledR}$ (Bacillus subtilis C-3102) in weaned piglets: Combined analysis of four different studies. J. Appl. Anim. Nutr. 2012, 1. [CrossRef]

12. Kritas, S.K.; Marubashi, T.; Filioussis, G.; Petridou, E.; Christodoulopoulos, G.; Burriel, A.R.; Tzivara, A.; Theodoridis, A.; Pískoriková, M. Reproductive performance of sows was improved by administration of a sporing bacillary probiotic (Bacillus subtilis C-3102). J. Anim. Sci. 2015, 93, 405-413. [CrossRef] [PubMed]

13. Michiels, J.; Possemiers, S.; DeGroote, J.; Ovyn, A.; De Smet, S.; Nakamura, N. Feeding Bacillus subtilis C-3102 to sows and suckling piglets and to weaned piglets improves parameters of gut health and feed:gain ratio in weaners. J. Anim. Sci. 2016, 94, 135-137. [CrossRef]

14. NRC. Nutrient Requirements of Swine, 11th ed.; National Academy Press: Washington, DC, USA, 2012.

15. Yang, Y.; Park, J.; Kim, I. Effect of probiotic containing Lactobacillus plantarum on growth performance, nutrient digestibility, and fecal microbiota in weaning pigs. Can. J. Anim. Sci. 2020, 100, 205-209. [CrossRef]

16. Fenton, T.W.; Fenton, M. An improved procedure for the determination of chromic oxide in feed and feces. Can. J. Anim. Sci. 1979, 59, 631-634. [CrossRef]

17. AOAC. Official Methods of Analysis, 17th ed.; Assoc. Off. Analysis Chemistry: Gaithersburg, MD, USA, 2000.

18. Williams, C.H.; David, D.J.; Iismaa, O. The determination of chromic oxide in faeces samples by atomic absorption spectrophotometry. J. Agric. Sci. 1962, 59, 381-385. [CrossRef]

19. Hu, C.H.; Gu, L.Y.; Luan, Z.S.; Song, J.; Zhu, K. Effects of montmorillonite-zinc oxide hybrid on performance, diarrhea, intestinal permeability and morphology of weanling pigs. Anim. Feed Sci. Technol. 2012, 177, 103-115. [CrossRef]

20. Medel, P.; Esteve-García, E.; Kritas, S.; Bontempo, V.; Marubashi, T.; McCartney, E.; Sánchez, J. Efficacy of a probiotic (Bacillus subtilis C-3102) in weaned piglets. In Proceedings of the 60th Annual Meeting of the EAAP, Barcelona, Spain, 24-27 August 2009; p. 515.

21. EFSA. EFSA Panel on Additives and Products or Substances used in Animal Feed (FEEDAP); Scientific Opinion on the safety and efficacy of Calsporin ${ }^{\circledR}$ (Bacillus subtilis) as a feed additive for piglets on request from the European Commission. EFSA J. 2010, 8, 1426. [CrossRef]

22. Dänicke, S.; Döll, S. A probiotic feed additive containing spores of Bacillus subtilis and B. licheniformis does not prevent absorption and toxic effects of the Fusarium toxin deoxynivalenol in piglets. Food Chem. Toxicol. 2010, 48, 152-158. [CrossRef]

23. Menegat, M.B.; Vier, C.M.; Cemin, H.S.; Shawk, D.; DeRouchey, J.M.; Woodworth, J.C.; Tokach, M.D.; Dritz, S.S.; Goodband, R.D. Effect of Calsporin on Nursing Piglet Growth Performance and Fecal Microflora. Kans. Agric. Exp. Stn. Res. Rep. 2017, 3, 9. [CrossRef]

24. Chesson, A. Probiotics and other intestinal mediators. In Principles of Pig Science; Cole, D.J.A., Wiseman, J., Varley, M.A., Eds.; Nottingham University Press: Loughborough, UK, 1994; pp. 197-214.

25. Hentges, D. Gut flora and disease resistance. In Probiotics: The Scientific Basis; Fuller, R., Ed.; Chapman and Hall: London, UK, 1992; pp. 87-110.

26. Savage, D.C. Microbial Ecology of the Gastrointestinal Tract. Annu. Rev. Microbiol. 1977, 31, 107-133. [CrossRef] [PubMed]

27. Kim, J.D.; Chung, H.W.; Shim, K.S.; Park, S.Y.; Ju, J.C.; Song, J.J.; Lee, K.H.; Park, J.K.; Park, D.Y.; Kim, C.H. Effects of probiotics as an alternative for antibiotics on growth performance, nutrient digestibility, noxious gas emission and fecal microbial population in growing piglets. Korean J. Organic Agri. 2010, 4, 527-539.

28. Devi, S.M.; Kim, I. Effect of medium chain fatty acids (MCFA) and probiotic (Enterococcus faecium) supplementation on the growth performance, digestibility and blood profiles in weanling pigs. Vet. Med. 2014, 59, 527-535. [CrossRef]

29. Patarapreecha, P.; Jaikan, W.; Juangsaman, A.; Khajarern, J. Effects of Dietary Bacillus subtilis Supplementation as Probiotics on Growth Performance and Nutrients Digestibility in Fattening Pigs. Pak. J. Nutr. 2018, 17, 634-640. [CrossRef]

30. Giang, H.H.; Viet, T.Q.; Ogle, B.; Lindberg, J.E. Effects of Supplementation of Probiotics on the Performance, Nutrient Digestibility and Faecal Microflora in Growing-finishing Pigs. Asian-Australas. J. Anim. Sci. 2011, 24, 655-661. [CrossRef]

31. Kornegay, E.T.; Risley, C.R. Nutrient digestibilities of a corn-soybean meal diet as influenced by Bacillus products fed to finishing swine. J. Anim. Sci. 1996, 74, 799-805. [CrossRef] [PubMed] 
32. Chen, Y.J.; Son, K.S.; Min, B.J.; Cho, J.H.; Kwon, O.S.; Kim, I.H. Effects of Dietary Probiotic on Growth Performance, Nutrients Digestibility, Blood Characteristics and Fecal Noxious Gas Content in Growing Pigs. Asian-Australas. J. Anim. Sci. 2005, 18, 1464-1468. [CrossRef]

33. Kim, J.; Hansen, C.; Mullan, B.; Pluske, J. Nutrition and pathology of weaner pigs: Nutritional strategies to support barrier function in the gastrointestinal tract. Anim. Feed Sci. Technol. 2012, 173, 3-16. [CrossRef]

34. Yan, L.; Hong, S.M.; Kim, I.H. Effect of Bacteriophage Supplementation on the Growth Performance, Nutrient Digestibility, Blood Characteristics, and Fecal Microbial Shedding in Growing Pigs. Asian-Australas. J. Anim. Sci. 2012, 25, 1451-1456. [CrossRef]

35. Jang, Y.-D.; Oh, H.-K.; Piao, L.-G.; Choi, H.-B.; Yun, J.-H.; Kim, Y.-Y. Evaluation of Probiotics as an Alternative to Antibiotic on Growth Performance, Nutrient Digestibility, Occurrence of Diarrhea and Immune Response in Weaning Pigs. J. Anim. Sci. Technol. 2009, 51, 25-32. [CrossRef]

36. Jonsson, E.; Conway, P. Probiotics for pigs. In Probiotics: The Scientific Basis; Fuller, R., Ed.; Chapman and Hall: London, UK, 1992 pp. 260-316.

37. Ichikawa, H.; Kuroiwa, T.; Inagaki, A.; Shineha, R.; Nishihira, T.; Satomi, S.; Sakata, T. Probiotic bacteria stimulate gut epithelial cell proliferation in rat. Am. J. Dig. Dis. 1999, 44, 2119-2123. [CrossRef]

38. Ross, G.R.; Gusils, C.; Oliszewski, R.; de Holgado, S.C.; González, S.N. Effects of probiotic administration in swine. J. Biosci. Bioeng. 2010, 109, 545-549. [CrossRef] [PubMed]

39. Cui, C.; Shen, C.; Jia, G.; Wang, K. Effect of dietary Bacillus subtilis on proportion of Bacteroidetes and Firmicutes in swine intestine and lipid metabolism. Genet. Mol. Res. 2013, 12, 1766-1776. [CrossRef] [PubMed]

40. Larsen, N.; Thorsen, L.; Kpikpi, E.N.; Stuer-Lauridsen, B.; Cantor, M.D.; Nielsen, B.; Brockmann, E.; Derkx, P.M.F.; Jespersen, L. Characterization of Bacillus spp. strains for use as probiotic additives in pig feed. Appl. Microbiol. Biotechnol. 2013, 98, 1105-1118. [CrossRef] [PubMed]

41. Konstantinov, S.R.; Awati, A.A.; Williams, B.A.; Miller, B.G.; Jones, P.; Stokes, C.R.; Akkermans, A.D.L.; Smidt, H.; de Vos, W.M. Post-natal development of the porcine microbiota composition and activities. Environ. Microbiol. 2006, 8, 1191-1199. [CrossRef] [PubMed]

42. Ferket, P.R.; Heugten, E.V.; Kempen, T.A.T.G.V.; Angel, R. Nutritional strategies to reduce environmental emissions from non-ruminants. J. Anim. Sci. 2002, 80, 168-182. [CrossRef]

43. Yan, L.; Meng, Q.; Kim, I. The effect of an herb extract mixture on growth performance, nutrient digestibility, blood characteristics and fecal noxious gas content in growing pigs. Livest. Sci. 2011, 141, 143-147. [CrossRef]

44. Han, I.K.; Lee, J.H.; Piao, X.S.; Li, D. Feeding and Management System to Reduce Environmental Pollution in Swine ProductionReview. Asian-Australas. J. Anim. Sci. 2001, 14, 432-444. [CrossRef]

45. Upadhaya, S.D.; Kim, S.C.; Valientes, R.A.; Kim, I.H. The Effect of Bacillus-based Feed Additive on Growth Performance, Nutrient Digestibility, Fecal Gas Emission, and Pen Cleanup Characteristics of Growing-finishing Pigs. Asian-Australas. J. Anim. Sci. 2015, 28, 999-1005. [CrossRef]

46. Chen, Y.; Min, B.; Cho, J.; Kwon, O.; Son, K.; Kim, H.; Kim, I. Effects of Dietary Bacillus-based Probiotic on Growth Performance, Nutrients Digestibility, Blood Characteristics and Fecal Noxious Gas Content in Finishing Pigs. Asian-Australas. J. Anim. Sci. 2006, 19, 587-592. [CrossRef]

47. Wang, Y.; Cho, J.; Chen, Y.; Yoo, J.; Huang, Y.; Kim, H.; Kim, I. The effect of probiotic BioPlus $2 \mathrm{~B}^{\circledR}$ on growth performance, dry matter and nitrogen digestibility and slurry noxious gas emission in growing pigs. Livest. Sci. 2009, 120, 35-42. [CrossRef]

48. Lan, R.; Tran, H.; Kim, I. Effects of probiotic supplementation in different nutrient density diets on growth performance, nutrient digestibility, blood profiles, fecal microflora and noxious gas emission in weaning pig. J. Sci. Food Agric. 2016, 97, 1335-1341. [CrossRef] [PubMed]

49. Banwart, W.L.; Brenmer, J.M. Identification of sulfur gases evolved from animal manures. J. Environ. Qual. 1975, 4, 363-366. [CrossRef] 